\title{
A Preliminary Assessment of an "Uncharted" Ecotourism Asset: The Case of Esori Waterfall in Cross River State, South Eastern Nigeria
}

\author{
Anim O. Ajake, Francis E. Bisong and Eze B. Eze \\ Department of Geography and Environmental science,University of Calabar, Calabar-Nigeria
}

\begin{abstract}
This study presents Esori waterfall to the world. Esori is a hitherto unknown waterfall undocumented anywhere in the local, national or international inventory or literature on waterfall but only known to the natives who reside within its precincts. The authors became aware of this asset in the course of undertaking a UK - DFID sponsored land evaluation and planning study for the Cross River State forestry commission in the year 2000. A preliminary assessment of the waterfall was thus made for the purpose of projecting its unique features to the world. In order to obtain adequate data, direct field observation and measurement of the river profile and biophysical assessment of the waterfall site was carried out. A participatory assessment through informal discussion and transect walk along the forest path of the Esori waterfall area was also conducted to supplement information from field measurements. Analysis of data was basically descriptive, capturing the details of waterfall. The study investigation highlights the features of the waterfall focusing on its location, physiography, vegetation, climate, population, site characteristics and tourism potentials. Based on these findings, the study recommends a detailed evaluation and development of Esori waterfall for ecotourism enhancement in Cross River State, South Eastern Nigeria.
\end{abstract}

Keywords: Esori waterfall, Cross River State, Etara/Ekuri-Eyeyeng, South- Eastern Nigeria, tourism, ecotourism

\section{Introduction}

Attention has been paid in the literature paid to the recent increase in scientific and educational tourism, in which the people seek opportunities for nature and the development of unique areas as tourism destinations. According to Cunningham and Cunningham (2004), the demands of increasing number of tourists attracted by natural environment of coastal areas should be a major consideration in development planning. These natural features include underwater life, coastal landforms such as waterfalls, caves and blow holes as well as coastal forests. The attraction of unique or unspoiled sites cannot be overestimated. While, many tourists may not fully appreciate the natural value of such sites, their beauty is a great asset to a region's resource, which needs to be carefully safeguarded as an integral part of tourism development. Chokor (1993), observed that interest in natural and cultural environments have formed the integral part of economic and human society especially in developing countries. Natural environments are resources and scenes of nature while cultural environments are creations of man often expressed in the physical landscapes. Most environments are creations of man often expressed in the physical landscapes. Most environmental resources recognized for their tourism potentials in the world are found to occur in distinct patterns termed environmental corridors, whose combined features had more recreational significance than individual resource pattern (Strahler \& Strahler, 1978, Cunningham \& Cunningham, 1999).

Several scholars (Chokor, 1993, Aremu, 2001 \& Fragbile, 2006) are generally on the view that ecotourism is aimed at developing relatively undisturbed and natural areas. Such natural features or potentials should be identified and given proper evaluation in terms of protection and management with a view to developing them into viable tourism destinations. Unfortunately, most natural sites/ features such as waterfalls are yet to be given attention in terms of their identification and assessment for tourism purposes in Nigeria. The identification and assessment of scenic qualities should be the major concern in landscape evaluation for tourism development. However, Eja, Ajake and Effiom (2012), found that lack of community awareness and positive attitudes of the people has lead to the abuse of ecotourism potentials, which has further depleted the environment for attractions.

While Amalu, Ajake, Oba and Okpara (2012) discovered that the careless and less-concerned attitude of the people about the content and state of 
their natural environment has negatively impacted the volume of tourists into Enugu. Other studies such as Ajake and Amalu (2012), Aniah, Okim, Eja and Ajake (2011) have attributed the development of ecotourism potentials such as lakes and mountains as the basis of socio-economic development in Cross River State. Despite the growing influence of tourism and its potential to boost local, regional and national economies the world over, a key setback to tourism development in Nigeria remains the paucity of reliable data and information on existing tourism assets (Bisong, 2002). Very little is known about the cultural and ecotourism assets of Nigeria, a situation which is tantamount to an exercise in futility or an empty ritual when issues such as tourism promotion and marketing are discussed. Promoting and marketing the enormous tourism potentials of the nation remains a far dream until appropriate identification documentation, classification and evaluation of the existing tourism assets are made (Bisong, 2002).

This piece of write-up is dedicated to bringing to the attention of policy makers, the academia, and the development community; the existence of an unknown (except to the natives), unexplored and undocumented asset of significant scenic attraction that holds much promise for the development of ecotourism. This is the Esori waterfall. This was stumbled upon in the last quarter of the year 2000 by a team of land use consultants scheduled to undertake a land use plan for the sustainable management of the forest of Etara/Ekuri Eyeyeng in Cross River State, South-Eastern Nigeria. It was thought by the team to do a preliminary assessment of the geographical and ecological features of the waterfall in order to document its essential attributes for posterity, with the hope that this may attract sufficient interest for its further development into a viable eco-tourism product.

\section{Methodology}

The assessment was based on the collection of primary data which was supported by information from secondary sources. The primary data collection entailed direct observation and measurement of the river profile and biophysical assessment of the waterfall site. This was achieved through a walk within dense tropical forest along the trail leading to the waterfall site. An assessment of vegetation structure and species composition of the flora and fauna was made during the walk. Through direct observation and cross checking with secondary references, the topographic, geomorphologic and geologic attributes of the waterfall site was determined. A participatory assessment through informal discussion with local guides who were professional hunters was helpful in making a judgment about the vegetation, land use, and folklore associated with the site. The Global Positioning System (GPS) was helpful in determining the geographic coordinate of the waterfall as well in estimating its width and length. Oral interviews, ocular estimates, and site measurements with poles were used in determining the depth of the waterfall.

\section{Findings}

\section{Geographical description of Esori waterfall}

Esori waterfall is located in the twin settlement of the Etara and Ekuri- Eyeyeng community in the southern section of the Etung local government area of Cross River State, South-Eastern Nigeria. The settlements lie between longitudes 8029' $\mathrm{E}$ and $8035^{\prime} \mathrm{E}$ and latitudes $5045^{\prime} \mathrm{N}$ to $5050^{\prime} \mathrm{N}$. Esori waterfall is located in the youthful section of the Ukpon River, a tributary of the Cross River to the south of Ikom town. The waterfall is precisely located at longitude 08028" 57'E and latitude 05048" 58'N (Figure.1). Figure 2 is a community drawn map showing the community appreciation of Esori waterfall as a potential eco-tourism site within the context of the community land use plan. This is supported by a drawn to scale map of Etara/Ekuri-Eyeyeng (Figure 1) showing the location of Esori waterfall along the Ukpon River (Figure 1).

\section{Physiography}

The Esori waterfall is within a moderately lowland area along the Ukpon river valley. The waterfall with its undulating topography is situated within the geomorphologic basin known as the Ikom - Manfe depression. Geologically speaking, the region belongs to the Oban Massif, a basement complex rock composed of metamorphic rocks of largely schist's and gneisses (Ekwueme, Itaya \& Yabe, 2000). They are metasedimentary rocks derived from pelithic protolith. The Ikom - Mamfe depression where the waterfall is located is dominantly a sedimentary terrain of the Eze-Aku formation (Essien-Umoh, 1981). It is characterized by a thick sequence of sandstones and clays of early cretaceous age (Peters, 1990). 


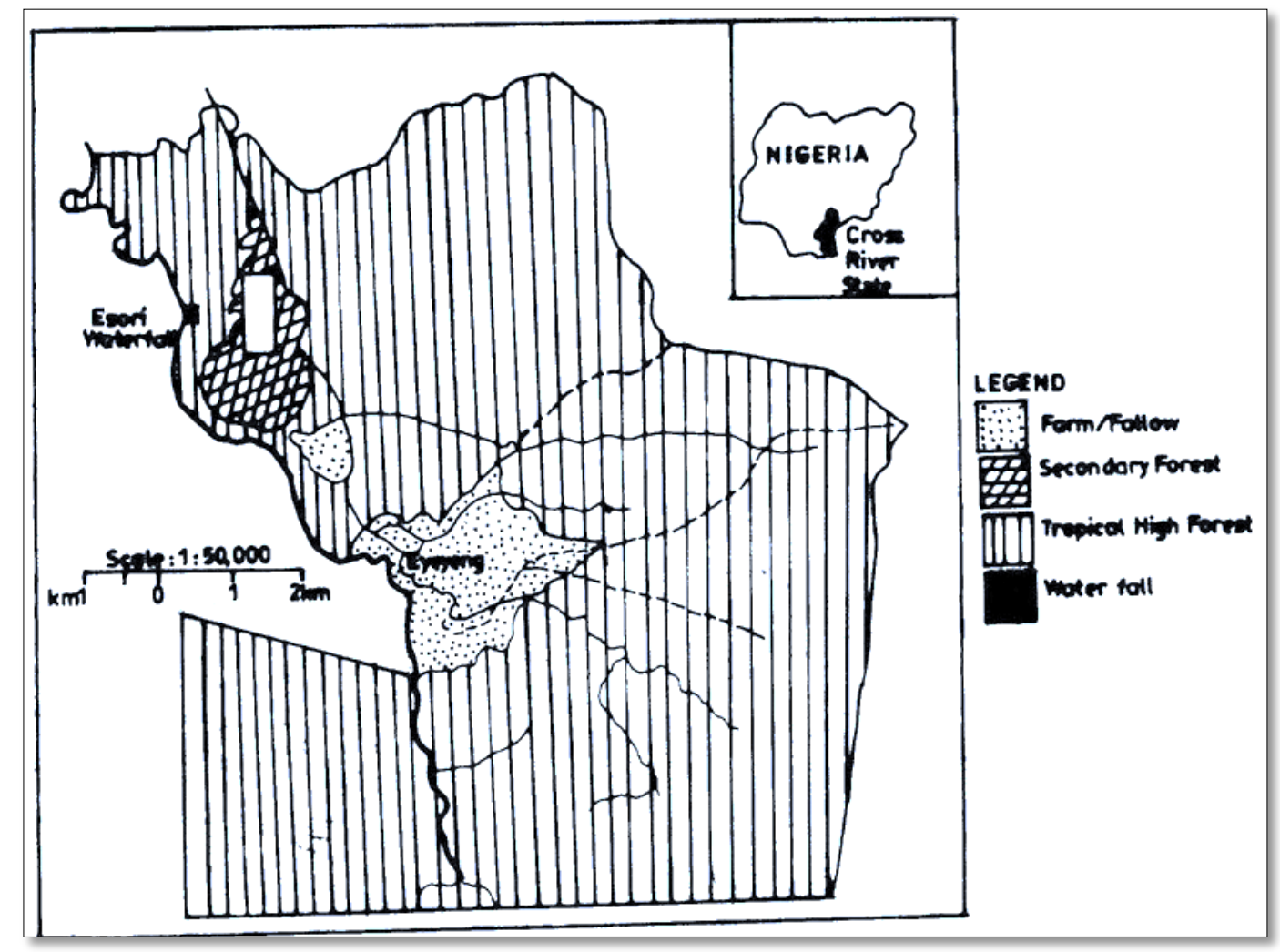

Figure 1. Map of Etara/Eyeyeng showing the location of Esori waterfall along the Ukpon River

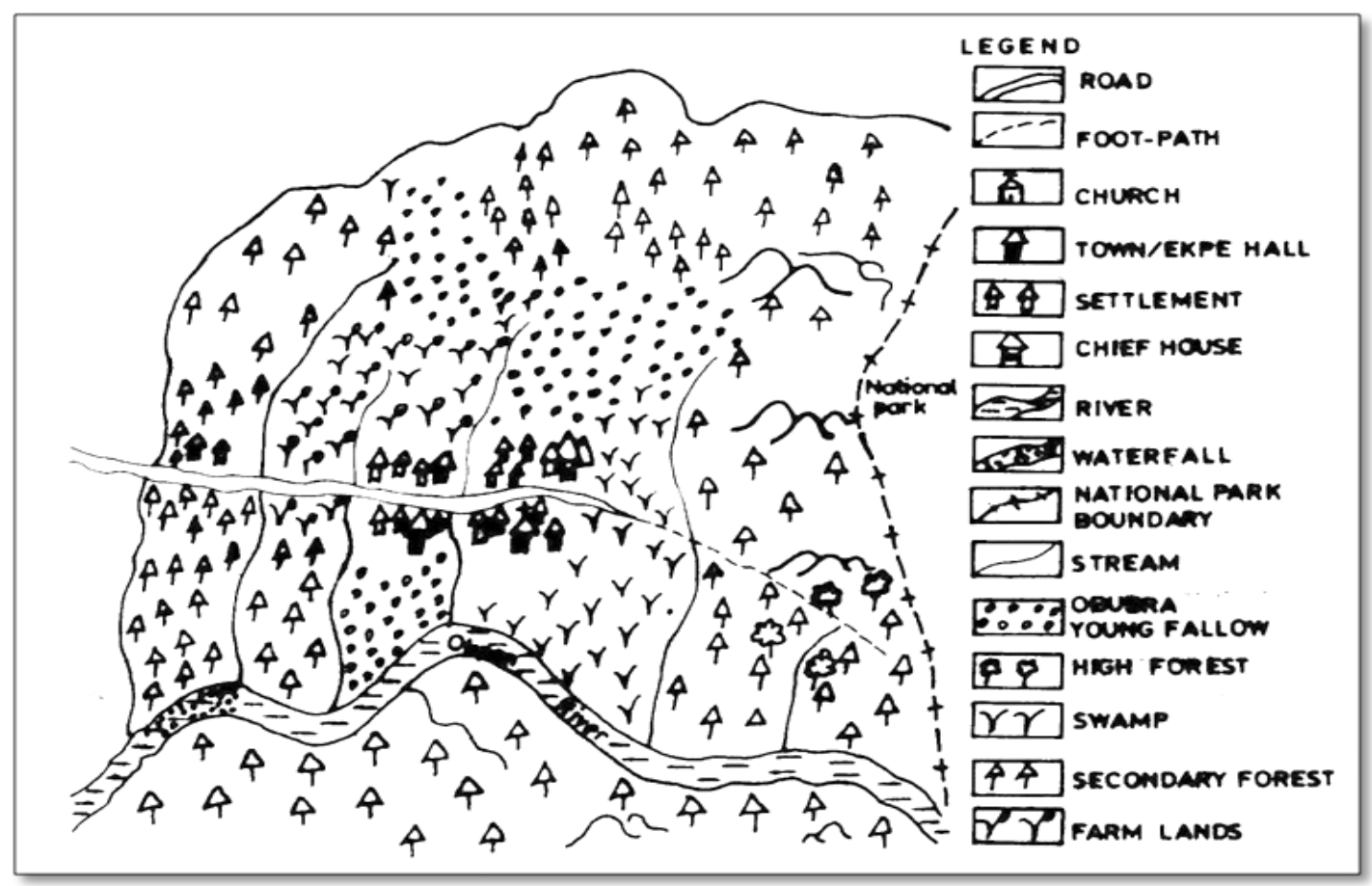

Figure 2. Community drawn map of Ettara/Eyeyeng showing vegetation, land use waterfall site. 
At the waterfall itself, there is observed igneous intrusions of mainly dolerite and diorite. They dominate the high relief area of Esori in the form of rock outcrops, and also form a sill across the Ukpon River throughout the stretch of the waterfall. The relief of the Esori waterfall is generally between $400 \mathrm{ft}(121 \mathrm{~m})$ above sea level.

\section{Climate}

The Esori region has an average total annual rainfall of $2314 \mathrm{~mm}$. With respect to its seasonality and monthly distribution of rainfall, Esori has about 3 dry months and between 8 to 9 wet months (Bisong, 2001). The average total annual volume of precipitation and pattern of monthly distribution depicts Esori as characteristically a region of tropical moist/wet forest. Average monthly temperature at lower elevations of up to $410 \mathrm{ft}(121 \mathrm{~m})$ above sea level, range between $26^{\circ} \mathrm{C}$ to $28^{\circ} \mathrm{C}$. At higher attitudes in the Etara/Ekuri-Eyeyeng settlements, temperature range from $24^{\circ} \mathrm{C}$ about $1350 \mathrm{ft}(409 \mathrm{~m})$ of elevation to $22.4^{\circ} \mathrm{C}$ in the highest elevation of $2550 \mathrm{ft}$ (773m) above sea level.

\section{Vegetation, biodiversity and soil}

The vegetation is characteristically that of the tropical moist and wet forest with a well defined three layer structure in much of the region. A pristine wet forest can be observed in the land area adjoining both sides of the waterfall. A combination of pristine and mature secondary re-growth forests is to be observed in the rest of the area east of the Ukpon River. The tree canopy cover, range between $40-80 \%$ in the secondary re-growth areas to greater than $80 \%$ in the dense forest area. The species assemblage common in the water fall site at under $750 \mathrm{ft}(227 \mathrm{~m})$ elevation are; Calpocalyx winkleri, Albizia zygia, Terminalia ivorensis, Pterocarpus Osun, Elaeis guineensis, Musunga cercropeoides and Irvingia gabonensis among others. At altitudes above $750 \mathrm{ft}(227 \mathrm{~m})$ are Pterocarpus Osun, Klainedoxa gabonensis and Lannea weiwitschii among others. The soils are generally acid crystalline rocks, shallow to moderately deep. Texturally speaking, the soil varies from loamy sand, sandy loam to sandy clay loam. They are generally well drained but poorly drained in some sections. The soils are generally of moderate fertility status.

\section{Population, economy, accessibility and linkages}

From projected estimates the population of the two forest communities where Esori waterfall is located is estimated at 1,653 persons. Detail figures of the population shows that Etara has 887 persons dwelling in about fifty-six (56) housing units, while that of Eyeyeng is estimated at 766 persons in sixty one (61) houses. The 1991 Nigeria census figure however put the population of the two communities at 1213 persons. The crude population density from the above estimate (2008 survey data) is 23 persons per sq $\mathrm{km}$.

This is indeed very low and confers on the community a land surplus status relative to most other settlements in the Cross River State. The economy of Eyeyeng and Etara is largely based on agricultural production, forest product extraction and hunting. Other forms minor sources of employment are craft making, government occupation and traditional medicinal attendants. Major staples are Yams, Cassava, Cocoyam, Plantain, Banana and assorted vegetables. Cocoa, bush mango and fruit trees are also cultivated. Forest products commonly harvested and traded are salad (Gnetum africanum, bush mango (Irvingia gabonensis), cane rope (Eremospatha macrocarpa), roofing mat (Raphia hookeria) and achi (Barchystegia kennedyli) among others. A thriving and lucrative bush meat trade exist Commonly hunted species are the porcupine, frutambo, red deer, monkey, the drill, pangolin and bush pig among others. Economic activities in Etara and Eyeyeng communities are seriously constrained due to the absence of access roads. A well defined periodic market does not exist in Etara/Eyeyeng, external buyers however do come into purchase produce grown or harvested by the locals. The products are usually underpriced as the absence of roads limits the bargaining power of the local producers. The location of the Esori waterfall at the heart of tropical moist forest makes the area inaccessible except using hunters track and minor footpaths. However, the only route from Calabar Ikom highway (Odonget Junction in Obubra local government area) has many wooden and fragile bridges across streams. In addition, the route is interrupted at several points by big trees falling across, thus blocking easy movement of people to the fall. The inaccessibility of the Esori waterfall is clear indication of its uncharted character.

\section{Site characterization of Esori waterfall}

The existence of the Esori waterfall was unknown to the outside world until it was discovered by the study team along the youthful section of the Ukpon River, a tributary of the Cross River. The waterfall sight depicts a series of plunge pools, about three in all cascading across a stretch of between $400 \mathrm{~m}$ to $600 \mathrm{~m}$ of river length. Precisely, the fall stretches over $400 \mathrm{~m}$ in width and about $600 \mathrm{~m}$ in length. The uniqueness of the Esori waterfall is seen in the two major steps of fall. The first step fall over 10 metres in height from 
the Plateau to the plunge pool, while the second step is about 6 metres in height. Esori water fall flows with powerful force over the underlying hard rock outer crops made up of dolerites and diorites along the Ukpon River. The noise bustle and rumbling that emanate from the fall in the words of the local 'seem to wrap itself around you like a heavy blanket'.

Due to the nature of the underlying igneous rock structure, the river bed is separated into several waterfalls within the same width and channel. The steep walls at the centre and bank of the river are distinctly outstanding with the plunge pool and band of dolerite sill across the river channel. The band of resistant rocks makes the water plunged down the edge of the precipice to form a pool. The magnificent nature of the Esori fall varies according to dry and rainy seasons. During the rainy season, hundreds of thousands of tons of water crash to the bottom of the fall each minute. When the water hits the floor of the chasm, it is estimated to move over $70 \mathrm{mph}$. After its plunge, the foaming water flows into a vast canyong, these sprays out bubbles of air and vapour unto the sky and creating an impressive "echo chamber" for the roar of the waterfall. It is visibly a unique landform of ecotourism significance, which is yet unknown and therefore not developed as tourism destination site in the rainforest of Cross River State, South Eastern Nigeria.

\section{Tourism potential of Esori waterfall}

The ecotourism potential of Esori fall is quite high. It holds a strong appeal to the natives for its aesthetic and spiritual value. Besides the two parallel falls separated by a band of walls within the same width, there is wonderful array of rocks and a dense typical tropical jungle with games. The uniqueness of the fall is also found in the preferences of the local population based on their active expression for swimming, boating, sightseeing and camping. The pristine beauty of the rainforest around the waterfall may also constitute the home environment of many fauna and flora species which can be of interest to tourists from within and outside Nigeria. The economy of Etara/Ekuri -Eyeyeng communities is strongly based on wildlife, hunting and collection of NTFPs. Presently; there are six major hunting grounds which are also sources of NTFP collection. The Bush Pig, Red Dear, Porcupine, (pangolin, Tortoise, Monkey, Chimpanzee, and the Drill are commonly hunted animals. The ecotourism potentials of some of the charismatic species such as Monkey, Chimpanzee, and Drill are huge if conserved and integrated into a string of attractions connected with the waterfall. The natives have interestingly demarcated the waterfall site and its adjoining districts into the ecotourism development zone within their proposed community land use plan (Figure 2).

In their words, they state categorically that "we want our excellent tourist attractions such as the waterfall and Onughi hills... to be developed in order to open up our community to other development influence as well as enable us protect our culture, craft and forest products to outsiders. This we believe will increase our income" (Bisong, 2001). Among the specific request put forward to achieve this dream is the development of an access road to Esori waterfall, development of a guest house for tourist, and construction of a nature trail to Esori waterfall and the Onughi hills to enable access and improve their attraction. The immeasurable and scenic properties of Esori waterfall, makes it necessary for government and stakeholders to harness this valuable resource for enhanced economic growth and tourism development in Cross River State, South Eastern Nigeria.

\section{Conclusion}

Tourism has become a critical factor in the socioeconomic development of most nations. The exploration of tourism potentials is therefore a pivot to development. Most tourism potentials especially in Cross River State are yet to be known by tourists. Since natural sites play a major role ecotourism development, it is therefore essential that they be identified for purpose of unfolding their potentials to the people. Proper identification should be a major aspect of inventory.

The study shows that Esori waterfall possesses scenic quality ranging from the nature of the fall, pristine rainforest vegetation, and wonderful array of rocks, favourable climate conditions and unique features of aesthetic value. A detailed evaluation and development of this fall is necessary for ecotourism to be sustained in Cross River State, South Eastern Nigeria. Besides, it would increase the number of tourists, enhanced socio-economic welfare of people and increase the gross domestic product (GDP) of Nigerian nation.

\section{References}

Ajake, A. O. \& Amalu (2012). Participation of development of becheeve people in tourism development in Obudu Mountain Resort, Cross River State" British Journal of Humanities and Social Science, 3(2), 16-33.

Ajake, A. O. \& Amalu (2012). The relevance of tourism on the economic development of Cross River State, Nigeria" in Journal of Geography and Regional Planning, 5(1), 14-20,

Amalu, T. E., Ajake, A. O.; Oba, D. O.\& Okpara, D. E. (2012): Assessment of the influence of education on tourism 
development in Enugu State, Nigeria. American Journal of Tourism Research, 1(1), 33-42.

Aniah, E. J.; Okim, D. O.; Eja, E. I.; \& Ajake, A. O. (2011). The spatial distribution analysis and composition of lakes as ecotourism potentials in cross River State, Nigeria, International Journal of Environmental Science, 7(3), 37-43.

Aremu, D. A. (2001). Cultural and eco-tourism development in Nigeria: The role of the three tiers of government and private sector, Hope Publications, Ibadan.

Bisong, F. E. (2001). Etara/Ekuri- Eyeyeng community land use plan. DFID-CRS Community Forestry Project -CRS Forestry Commission, Calabar.

Bisong, F. E. (2002). Developing the cultural and ecotourism potential in Cross River State, South -eastern, Nigeria: An unpublished Paper.

Chokor, B. A. (1993). Perspectives on Environment and tourism in Nigeria" In Chokor, B. A. (ed), Environment and tourism in Nigeria, pp. 1-12.

Cunningham, W. P. \& Cunningham, M. A. (2004). Principles of environmental science: Inquiry and applications $\left(2^{\text {nd }}\right.$ edition), McGraw-Hill Higher Education, USA.
Eja, E. I., Ajake, A. O., Effiom, V. A. (2012). Assessment of community perception of participation in Eco-tourism: Cross River State National Park Scenario, British Journal of Humanities and Social Sciences, 3(3), 1-11.

Ekwueme, B. N, Itaya, T \& Yabe, H. (2000). K-Ar ages of some metamorphic rocks of Oban massif and their implications for the tectonothermal evolution of South-eastern Nigeria, Jour. Min. Pet. Econ. Geol. 95(2).

Essien - Umoh, N. E. (1981). The geology of Ochon and Environs: B.Sc. Thesis submitted to the Department of Geology, Faculty of Science, University of Calabar.

Fagible, A. (2006). Development of eco-tourism in Nigeria, JulRose Enterprises, Abuja.

Nkwo, S. U. (1984). Geology of Ovakwu and Environs, B.Sc. Thesis submitted to the Department of Geology, University of Calabar, Nigeria.

Peters, S. W. (1990). The physical environment of the upper Cross River Area, In Jaja, S. O. et al (eds): History and culture of the Upper Cross River. Pp.1-12.

Strahler, A. N. \& Strahler, A. H. (1978). Modern physical geography, John Wiley and Sons, New York. 